Vol. 6(6), pp. 205-214, J une 2014

DOI: $10.5897 /$ J ENE12.093

Artic le Number. CB112C E45307

ISSN 2006-9847

Copyright (c) 2014

Journal of Ecology and the Natural Environment

Author(s) retain the copyright of this a ricle

http://www.academicjoumals.org/J ENE

\title{
Community Structure of Montane forest along the Altitudinal Gradient in Garhwal Himalaya, India
}

\author{
Minaxi Khali* and V P Bhatt \\ Department of Botany, Government PG College, Gopeshwar, Chamoli, Uttarakhand, India.
}

Received 4 October, 2012; Accepted 23 April, 2014

\begin{abstract}
The present study was done in sub-tropical and temperate Himalayan Forest of Saikot Reserve Forest, Kedarnath forest division in Chamoli district of Uttarakhand to understand the community structure and effect of altitudinal variation on structure and composition of the vegetation and to record the floristic diversity of the plants in the study area. The study area was categorized into four forest types on the basis of vegetation analysis, plant association or plant composition surveys, viz (1) Chir-Pine forest, (2) pine-oak forest (3) oak-pine-forest (4) oak-mixed forest. In the floristic study, a total of 58 species were recorded. Of the 58 plant species, 21 were tree, 11 shrubs and 26 herbs. The Quercus leucotrichophora forest was experiencing serious threat owing to human pressure and severe invasion of Pinus roxburghii which leads to loss of oak forest and development of pine forest.
\end{abstract}

Key words: Community structure, Saikot Reserve Forest, Garhwal Himalaya, altitudinal gradient, Montane Forest, aspects.

\section{INTRODUCTION}

Vegetation is a key factor in determining the structure of any ecosystem (Gaur, 1999; Bhatt and Purohit, 2009). Within a plant community, it determines microclimate, energy budget, photosynthesis, water regimes, surface runoff and soil temperature (Yadav and Gupta, 2006). The plant community of a region is a function of time and altitude. Slope, latitude, aspect, rainfall and humidity also play an important role in the formation of plant communities and their composition (Kharkwal et al., 2005).

The Himalayan vegetation ranges from sub-montane dry-deciduous forest in the foothills to alpine pasture above the timberline (Gaur, 1999; Bhatt and Purohit,
2009). The vegetation of Himalaya was intensively studied by Becking (1954). The literature on quantitative phytosociological work has been published from various parts of world (Cheema and Qadir, 1973; Beg and Khan, 1984; Ahmed et al., 2006; Ahmed et al., 2010; Khan et al., 2010a). Phytosociological characters differ among aspects and position, even in the same vegetation type. However, the different types of forest studies (structural and functional) in Garhwal Himalaya were shown by several workers such as Osmoston (1922), Puri (1960) and Champion and Seth (1968). Oak and other forest of Garhwal Himalaya has been studied for structure and

*Corresponding author. E-mail: bhattvp3@yahoo.com or khali15minaxi@gmail.com.

Author(s) agree that this article remain permanently open access under the terms of the Creative Commons Attribution License 4.0 International License 
succession, and for impact of biotic stress by several workers like Tiwari (1979), Tiwari and Gupta (1982), Agrawal (1985), Rawat and Tiwari (1990), Joshi and Tiwari (1990), Mehta and Tiwari (1992), Bisht and Kusumlata (1993), Gaur and Bartwal (1993), Bhandari et al. (1995), Agarwal (1996), Mehta et al. (1997), Nautiyal et al. (1997), Bhandari et al. (1997), Bhandari and Tiwari (1997), Bhandari et al. (2000) and Bhandari et al. (2003). In Western Himalaya, the formation is represented by Pinus roxburghii (Mehta and Bhandari, 1997). But possibly, this is not the potential natural climax forest and its extensive occurrence today would not have been possible, had there not been continuing disturbances such as landslides, burning, deforestations, etc (Champion and Seth, 1968a, b). However, these forests are now stabilized over a large area and are regarded as a permanent feature of the mountains of western Himalaya.

The pine species is the principal tree of the lower and middle region of Garhwal region of western Himalaya (750-2100m asl) and constitutes the main source for fuel and shows a specific impact on the economy and the ecology of this region. Therefore, in the present study, an attempt has been made to quantify the species composition and structure in Saikot forest as very little information exists on this aspect in north western Himalaya.

\section{MATERIALS AND METHODS}

\section{Study area}

Geographically, the study area (Saikot Reserve Forest) is between $30^{\circ} 21^{\prime} 23.2^{\prime \prime}$ to $30^{\circ} 22^{\prime} 47.6^{\prime \prime}$ north latitude and $79^{\circ} 17^{\prime} 45.0^{\prime \prime}$ to $79^{\circ}$ 17 ' 44.2" east longitude while attitudinally, it range from 800 to 2500 $\mathrm{m}$ asl and is the part of Gopeshwar range of Kedarnath Wild-life Forest Division of the district Chamoli.

Due to mountainous structure of the study area, it has varying altitude and relief which contribute greatly to variations in climatic condition. Owing to steepness of slopes, there are marked local effects due to differences in isolation. Temperature of the area fluctuates from time to time which makes specific micro-climate of the region. The average annual temperature of the region is $20^{\circ} \mathrm{C}$. The maximum temperature is recorded in April to June $\left(35^{\circ} \mathrm{C}\right)$ and minimum temperature in the valley recorded in the months of January-December $\left(8-15^{\circ} \mathrm{C}\right)$.

The average annual rainfall of the area is $130 \mathrm{~mm}$ (based on the data of Gopeshwar Range). The humidity is inversely proportional to temperature. Where the temperature increases, these humidity will decrease. Relative humidity reaches almost the absolute humidity during July and August (80-92\%). The minimum relative humidity reduces during the month of January-June and December (25$38 \%$ ). The average annual relative humidity of study area is $55 \%$ which decreases with increase in temperature and altitude.

\section{Soil}

The soil in a region varies according to altitude, climate and vegetation in its texture and structure, therefore may be categorized into four types viz., hard loamy soil, black loam soil, sandy loamy soil and sandy grey soil. Soil on the slope above $30^{\circ}$, due to erosion and mass wasting processes, are generally shallow and usually have very thin surface horizons. Such soils have medium to coarse texture.

\section{Methodology}

The vegetation was analyzed by laying the quadrate at different elevation (800 - $2500 \mathrm{~m}$ asl) and localities. The woody vegetation analysis was examined by using $10 \times 10 \mathrm{~m}$ randomly placed quadrates on each sites on each sampling date. In each quadrate, all trees $(>31.5 \mathrm{~cm} \mathrm{cbh})$ and saplings or shrubs $(10.50-31.40 \mathrm{~cm} \mathrm{cbh})$ were individually measured for circumference at breast height (cbh, that is, $1.37 \mathrm{~m}$ from the ground). For recording, the shrubs $5 \times 5 \mathrm{~m}$ size quadrat were laid while for herbaceous vegetation, $1 \times 1 \mathrm{~m}$ size quadrates were laid down randomly at each site separately. The vegetation data were analyzed quantitatively for abundance, density and frequency following the methods discussed by Curtis and Cottom (1956); species diversity $\left(\mathrm{H}^{-}\right)$was computed by Shannon-Wienner information function (Shannon-Wienner, 1963). Concentration of dominance (Cd) was computed by Simpson's index, (Simpson, 1949). $\beta$-Diversity was calculated by following the method of Whittaker (1975), while equitability (Ec) or species per log cycle index was determined following Whittaker (1972) and the community coefficient was calculated following Kulczynski (1927).

\section{RESULTS AND DISCUSSION}

The present study is based on extensive and intensive field study made during the months of September 2009 to September 2011 at various localities of Saikot Reserve Forest. The vegetation data were quantitatively analyzed for abundance, density and frequency according to the standard formulae.

A total of 58 plant species were recorded from the entire study area (Saikot Reserve Forest area Kedarnath forest division). Of 58 plant species, 21 were trees, 11 were shrubs and 26 were herbs. On the basis of plant association or plant composition surveys, the study area, can be categorized into four forest types viz, (1) Chir-Pine forest, (2) pine-oak forest (3) oak-mixed forest. The area can also be classified under four altitudinal gradients and aspects that is $800-1200 \mathrm{~m}$ asl (Site 1) at South-West aspect; 1200 - $1600 \mathrm{~m}$ asl (Site 2) at North-West aspect; $1600-2000 \mathrm{~m}$ asl (Site 3) at South-East aspect and 2000-2500 m asl (Site 4) at North-East aspect. The general features of the area are described in Table 1.

Site-wise (a total of 4 sites were studied in the area) of species distribution is presented in Table 2. Site 4 is relatively species poor than Sites 1 and 3 . Pinus roxburghii is dominant species at Sites 1 and 2 and Quercus leucotrichphora dominates Sites 3 and 4. Although dominance was shared by number of species, no single species was found to compete with Quercus leucotrichphora in Sites 3 and 4; a climax species. On the basis of density, basal cover and importance value index (IVI), P. roxburghii was found to be most important and dominant species in Sites 1and 2; whereas $Q$. leucotrichphora dominated Sites 3 and 4 (Table 3). However, the presence of $P$. roxburghii in Site 3 is an indication of possible threat to the coexistence of climax and 
Table 1. Site characteristics in the Saikot reserve forest area of Kedarnath forest division.

\begin{tabular}{lcccl}
\hline Site & Altitude (masl) & Slope $\left(^{\circ}\right.$ ) & Aspect & Forest types \\
\hline Saikot (Site 1) & $800-1200$ & 20 & SW & Chir-Pine (Pinus roxburghii) \\
Tangsa (Site 2) & $1200-1600$ & 25 & NW & $\begin{array}{l}\text { Pine-Oak (Pinius roxburghii, Quercus leucotrichophora, } \\
\text { Rhododendron arboreum) }\end{array}$ \\
Devkhal (Site 3) & $1600-2000$ & 35 & SE & $\begin{array}{l}\text { Oak-Pine (Pinius roxburghii, Quercus leucotrichophora, } \\
\text { Rhododendron arboreum) }\end{array}$ \\
Bamyala (Site 4) & $2000-2500$ & 50 & NE & $\begin{array}{l}\text { Oak-mixed (Quercus leucotrichophora, Q. floribunda, } \\
\text { Rhododendron arboreum, Myrica esculenta) }\end{array}$ \\
\hline
\end{tabular}

SW,South-East; NW, North-East; SE, South-East; NE, North East.

Table 2. Distribution of plant species in different sites of the study area.

\begin{tabular}{ccccc}
\hline Site & Tree & Shrub & Herb & Total \\
\hline 1 & 7 & 6 & 11 & 24 \\
2 & 7 & 4 & 7 & 18 \\
3 & 9 & 3 & 8 & 20 \\
4 & 6 & 4 & 6 & 16 \\
Total & $\mathbf{2 1}$ & $\mathbf{1 1}$ & $\mathbf{2 6}$ & $\mathbf{5 8}$ \\
\hline
\end{tabular}

and associated species (Table 3 ). The late successinal and climax species $Q$. leucotrichophora in the region when disturbed severely by human pressure as grazing, lopping, felling and burning, changes the microclimatic conditions and invites the invading species like $P$. roxburghii in the area (Semwal and Mehta, 1996). The total basal area of the trees ranged from 1346.59 to $19427.64 \mathrm{~m}^{2} \mathrm{~h}^{-1}$ and total density varied between 710 and $1140 \mathrm{~h}^{-1}$ across the Saikot Reserve Forest (Table 3). Total basal area and density of tree layer was reported in the range of $27-191.5 \mathrm{~m}^{2} \mathrm{~h}^{-1}$ and 350 to 1787 plants $\mathrm{h}^{-1}$, respectively, for various broad leaved, traditional conserved (sacred groove) and protected (Nanda Devi Biosphere Reserve) forests of Kumaun and Garhwal Himalaya (Saxena and Singh, 1982; Singh and Singh, 1987; Bhandari and Tiwari, 1997; Sinha and Maikhuri, 1998; Maikhuri et al., 2000). Higher values of basal cover density and lower values of density suggest that all sites are mature and climax in nature. Low tree density and less number of species in Site 4 reflect the forest is under high biotic pressure coupled with other abiotic factors which are not necessarily conducive for tree growth.

The number (density) of seedlings of any species can be considered as the regeneration potential of that species. From the density values (Table 3 ), it is concluded that the regeneration of oak ( $Q$. leucotrichophora) in Site 4 is low, as compared to Site 3 and regeneration of $P$. roxburghii in Site 2 is low, as compared to Site 1, but not in that level of harsh conditions as has been pointed out by other worker in other studied area of Central Himalaya (Saxena et al., 1978; Ralhan et al., 1982; Tiwari and Singh, 1982; Saxena and Singh, 1984; Bankoti et al., 1986). The co-dominance of $P$. roxburghii with $Q$. leucotrichophora particularly in Site 3 (Table 3 ) is an indication that due to various anthropogenic (human) pressures oak regenerates in comparison with pine. Degradation of the oak forest through high anthropogenic pressure will provide appropriate conditions for the pine (an early successional, low nutrient demander and shade intolerant species) to invade, thereby posing a serious threat to the ecological balance of this region (Singh et al., 1984).

In Saikot Reserve Forest, species richness is very high in herb layers (present study) as compared to other broad leaved forests of Garhwal Himalaya (Bhandari and Tiwari, 1997; Bhandari et al., 1998). High species richness in herb layers may be due to relatively less developed canopy in these mature forests which permit sufficient sunlight to reach the ground resulting in the luxuriant growth of herb species (Table 3).

A/F ratio was used to assess the distribution pattern of the species. Vegetation was found in haphazard distribution by most of the species followed by regular distribution. Contagious distribution as observed in the present case has not been reported in tree layers from this part of the Himalaya (Table 4). It is interesting that the distribution pattern of shrub and herbs did not correspond with the distribution pattern of trees. Other workers (Saxena and Singh, 1982; Bhandari and Tiwari, 1997) findings for Central Himalaya are different. Greig-Smith (1957), Kershaw (1973) and Singh and Yadava (1974) have reported contagious distribution in natural vegetation. Preponderance of random distribution in tree and shrubs layers as compared to herbs layer reflects the dimension of biotic interferences in these strata.

In the present study, similarity values have been shown in Table 6. It was interesting to note that Site 1 was completely dissimilar to Site 3 and Site 4 . This indicates that there is great influence of site characteristics (microclimatic variations, different aspect, soil composition and 
Table 3. Phytosociological analysis of tree vegetation.

\begin{tabular}{|c|c|c|c|c|c|c|c|}
\hline Site & Botanical name & $\mathbf{F}$ & $\mathbf{A}$ & $\mathrm{D}$ & TBC & IVI & $\mathrm{A} / \mathrm{F}$ \\
\hline & Tree & & & & & & \\
\hline & Pinus roxburghii & 100 & 4.20 & 4.20 & 10594.97 & 171.40 & 0.0420 \\
\hline & Bauhinia semla & 20 & 1.00 & 0.20 & 312.10 & 11.81 & 0.0500 \\
\hline & Terminalia alata & 30 & 1.33 & 0.40 & 642.17 & 20.42 & 0.0444 \\
\hline & Toona ciliata & 20 & 1.00 & 0.20 & 460.19 & 12.91 & 0.0500 \\
\hline & Bauhinia vareigata & 50 & 1.00 & 0.50 & 382.32 & 26.56 & 0.0200 \\
\hline & Emblica officinalis & 20 & 1.00 & 0.20 & 49.94 & 9.86 & 0.0500 \\
\hline & Engelharditia spicata & 60 & 2.33 & 1.40 & 984.90 & 47.05 & 0.0389 \\
\hline & & 300 & 11.87 & 7.10 & 13426.59 & 300 & \\
\hline & Sapling & & & & & & \\
\hline & Pinus roxburghii & 50 & 3 & 1.5 & 100.44 & 222.67 & 0.06 \\
\hline & Engelharditia spicata & 30 & 1.333 & 0.4 & 23.22 & 77.329 & 0.0444 \\
\hline & & 80 & & 1.90 & 123.65 & 300 & \\
\hline & Seedling & & & & & & \\
\hline & Pinus roxburghii & 50 & 3.2 & 1.6 & 1.15 & 209.27 & 0.064 \\
\hline & Engelharditia spicata & 30 & 1 & 0.3 & 0.14 & 54.255 & 0.0333 \\
\hline & Bauhinia semla & 20 & 1 & 0.2 & 0.10 & 36.736 & 0.05 \\
\hline & & 100 & & 2.1 & 1.38 & 300 & \\
\hline Site 1: Saikot & Shrub & & & & & & \\
\hline \multirow[t]{20}{*}{$(800-1200)$} & Woodfordia fruticosa & 60 & 2 & 1.2 & 38.22 & 74.149 & 0.0333 \\
\hline & Barberis asiatica & 80 & 2.125 & 1.7 & 34.65 & 85.914 & 0.0266 \\
\hline & Rubus ellipticus & 50 & 1.8 & 0.9 & 10.32 & 40.548 & 0.036 \\
\hline & Colebrookia oppositifolia & 50 & 1.6 & 0.8 & 6.37 & 35.194 & 0.032 \\
\hline & Rubus niveus & 40 & 1 & 0.4 & 3.85 & 22.747 & 0.025 \\
\hline & Solanum erianthum & 50 & 1.2 & 0.6 & 17.25 & 41.451 & 0.024 \\
\hline & & 330 & & 5.6 & 110.65 & 300 & \\
\hline & Herb & & & & & & \\
\hline & Cylindrica imperata & 60 & 3 & 1.8 & 1.29 & 41.927 & 0.05 \\
\hline & Cymbopogon nardus & 70 & 5.143 & 3.6 & 1.39 & 57.157 & 0.0735 \\
\hline & Themeda triandra & 40 & 2.25 & 0.9 & 0.64 & 23.004 & 0.0563 \\
\hline & Artemisia nilagirica & 50 & 3.8 & 1.9 & 0.61 & 31.073 & 0.076 \\
\hline & Heteropogon contortus & 30 & 6.667 & 2 & 0.64 & 28.09 & 0.2222 \\
\hline & Dicliptera bupleuroides & 40 & 2.25 & 0.9 & 0.64 & 23.004 & 0.0563 \\
\hline & Dioscorea bulbifera & 40 & 2 & 0.8 & 0.25 & 16.95 & 0.05 \\
\hline & Thysanolacna maxima & 40 & 2.5 & 1 & 0.32 & 19.147 & 0.0625 \\
\hline & Coleus froskei & 30 & 0.667 & 0.2 & 0.06 & 8.3192 & 0.0222 \\
\hline & Poa annua & 60 & 3 & 1.8 & 1.29 & 41.927 & 0.05 \\
\hline & Rumex hastatus & 30 & 1 & 0.3 & 0.10 & 9.4176 & 0.0333 \\
\hline & & 490 & & 15.20 & 7.23 & 300 & \\
\hline
\end{tabular}

F, Frequency; A, Abundance; D, Density; TBC, Total Basal Cover; IVI, Importance Value Index; A/F, Abundance/Frequency ratio.

variation in altitudinal gradient) on the composition of vegetation. However, Mehta et al. (1997) reported similarity of 9.6 (between burnt grazed and unburnt grazed sites) to $74.9 \%$ (between unburnt protected and unburnt grazed sites) for the various forest sites under different management regimes in Garhwal Himalaya. Wikum and Wali (1974) and Saxena and Singh (1982) have pointed out the significant role of the site characteristics in plant distribution and similarity.

The values of diversity are presented in Table 5 . 
Table 3. Contd.

\begin{tabular}{|c|c|c|c|c|c|c|c|}
\hline Site & Botanical name & $\mathbf{F}$ & $\mathbf{A}$ & D & TBC & IVI & $\mathrm{A} / \mathrm{F}$ \\
\hline & Tree & & & & & & \\
\hline & Pinus roxburghii & 80 & 3.625 & 2.9 & 7817.07 & 88.668 & 0.0453 \\
\hline & Quercus leucotrichophora & 100 & 4.4 & 4.4 & 8525.35 & 112.02 & 0.044 \\
\hline & Alnus nepalensis & 40 & 1.25 & 0.5 & 308.28 & 16.489 & 0.0313 \\
\hline & Pyrus pashia & 50 & 1.8 & 0.9 & 1569.55 & 29.403 & 0.036 \\
\hline & Lyonia ovalifolia & 50 & 1.2 & 0.6 & 832.36 & 22.667 & 0.024 \\
\hline & Salix babylonica & 20 & 1 & 0.2 & 146.75 & 7.7162 & 0.05 \\
\hline & Rhododendron arboretum & 60 & 1.167 & 0.7 & 228.28 & 23.038 & 0.0194 \\
\hline & & 400 & & 10.20 & 19427.64 & 300 & \\
\hline & Sapling & & & & & & \\
\hline & Pinus roxburghii & 50 & 1.8 & 0.9 & 64.49 & 141.85 & 0.036 \\
\hline & Quercus leucotrichophora & 50 & 1.2 & 0.6 & 32.29 & 98.09 & 0.024 \\
\hline & Alnus nepalensis & 30 & 1.333 & 0.4 & 18.34 & 60.063 & 0.0444 \\
\hline & & 130 & & 1.90 & 115.13 & 300 & \\
\hline \multirow{19}{*}{$\begin{array}{l}\text { Site 2: Tangsa } \\
(1200-1600)\end{array}$} & Seedling & & & & & & \\
\hline & Pinus roxburghii & 50 & 1.6 & 0.8 & 0.57 & 145.17 & 0.032 \\
\hline & Quercus leucotrichophora & 50 & 2 & 1 & 0.56 & 155.03 & 0.04 \\
\hline & & 100 & & 1.80 & 1.13 & 300 & \\
\hline & Shrub & & & & & & \\
\hline & Barberis asiatica & 70 & 2.143 & 1.5 & 30.57 & 107.05 & 0.0306 \\
\hline & Rubus ellipticus & 40 & 1.75 & 0.7 & 8.03 & 43.281 & 0.0438 \\
\hline & Colebrookia oppositifolia & 60 & 1.167 & 0.7 & 5.57 & 48.102 & 0.0194 \\
\hline & Rubus niveus & 60 & 4 & 2.4 & 19.11 & 101.57 & 0.0667 \\
\hline & & 230 & & 5.30 & 63.28 & 300 & \\
\hline & Herb & & & & & & \\
\hline & Agrostis nervosa & 40 & 3.5 & 1.4 & 0.70 & 33.075 & 0.0875 \\
\hline & Heteropogon contortus & 70 & 5 & 3.5 & 1.11 & 63.851 & 0.0714 \\
\hline & Arundinela nepalensis & 60 & 3.333 & 2 & 1.08 & 49.403 & 0.0556 \\
\hline & Bidens pilosa & 60 & 2.667 & 1.6 & 0.86 & 42.856 & 0.0444 \\
\hline & Cynodon dactylon & 50 & 4.2 & 2.1 & 1.04 & 46.834 & 0.084 \\
\hline & Ajuga bracteosa & 40 & 5 & 2 & 0.64 & 36.486 & 0.125 \\
\hline & Taraxacum officinale & 40 & 2.5 & 1 & 0.54 & 27.479 & 0.0625 \\
\hline & & 360 & & 13.60 & 5.97 & 299.98 & \\
\hline
\end{tabular}

F, Frequency; A, Abundance; D, Density; TBC, Total Basal Cover; IVI, Importance Value Index; A/F, Abundance/Frequency ratio.

Diversity is a combination of two factors, the number of species present, referred to as species richness and the distribution of individuals among the species, referred to as evenness or equitability. Single species populations are defined as having a diversity of zero, regardless of the index used. Species diversity therefore, refers to the variations that exist among the different forms. In the present study, Shannon-Wiener index of diversity was used. The value of diversity ranged from 0.8098 to $1.3266,0.66737$ to 1.2759 and 0.4377 to 0.5767 , respectively, for trees, shrubs and herbs in Saikot Reserve
Forest. The range of diversity in the present community forest stands is certainly lower than any other montane forests of Central Himalaya (Ralhan et al., 1982). Moderate amount of anthropogenic pressure on Saikot Reserve Forest is helpful in maintaining the higher species diversity. Such view was also expressed by Thadani and Ashton (1995) and Singh et al. (1997).

The value of beta-diversity ranged from 1.5789 to 2.3333, 1.5384 to 1.8181 and 1.0714 to 2.2916 for trees, shrub and herbs layers, respectively in Saikot Reserve Forest. These values are much lower than those 
Table 3. Contd.

\begin{tabular}{|c|c|c|c|c|c|c|c|}
\hline Site & Botanical name & $\mathbf{F}$ & A & D & TBC & IVI & $\mathrm{A} / \mathrm{F}$ \\
\hline \multirow{36}{*}{$\begin{array}{l}\text { Site 3: Devkhal } \\
(1600-2000)\end{array}$} & Tree & & & & & & \\
\hline & Quercus leucotrichophora & 100 & 4.6 & 4.6 & 8912.87 & 111.07 & 0.046 \\
\hline & Lyonia ovalifolia & 30 & 1 & 0.3 & 731.49 & 13.389 & 0.0333 \\
\hline & Pyrus pashia & 100 & 2.7 & 2.7 & 3802.57 & 66.887 & 0.027 \\
\hline & Myrica esculenta & 30 & 1 & 0.3 & 349.71 & 11.333 & 0.0333 \\
\hline & Rhododendron arboretum & 40 & 2.5 & 1 & 1494.35 & 25.909 & 0.0625 \\
\hline & Phoebe lanceolata & 50 & 2.2 & 1.1 & 1667.87 & 29.994 & 0.044 \\
\hline & Quercus floribunda & 40 & 2 & 0.8 & 917.20 & 21.047 & 0.05 \\
\hline & Persea duthiei & 30 & 1.333 & 0.4 & 571.85 & 13.406 & 0.0444 \\
\hline & Pinus roxburghii & 20 & 1 & 0.2 & 123.31 & 6.9638 & 0.05 \\
\hline & & 440 & & 11.40 & 18571.20 & 300 & \\
\hline & Sapling & & & & & & \\
\hline & Quercus leucotrichophora & 70 & 1.571 & 1.1 & 78.82 & 151.54 & 0.0224 \\
\hline & Lyonia ovalifolia & 60 & 1.167 & 0.7 & 37.68 & 96.939 & 0.0194 \\
\hline & Persea duthiei & 30 & 1.333 & 0.4 & 19.90 & 51.525 & 0.0444 \\
\hline & & 160 & & 2.20 & 136.40 & 300 & \\
\hline & Seedling & & & & & & \\
\hline & Quercus leucotrichophora & 100 & 2.6 & 2.6 & 1.86 & 181.41 & 0.026 \\
\hline & Lyonia ovalifolia & 60 & 1.667 & 1 & 0.62 & 77.171 & 0.0278 \\
\hline & Pinus roxburghii & 40 & 1.25 & 0.5 & 0.25 & 41.276 & 0.0313 \\
\hline & & 200 & & 4.10 & 2.74 & 299.86 & \\
\hline & Shrub & & & & & & \\
\hline & Daphne papyracea & 70 & 2.143 & 1.5 & 30.57 & 137.23 & 0.0306 \\
\hline & Pyracantha crenulata & 40 & 1.75 & 0.7 & 22.29 & 79.99 & 0.0438 \\
\hline & Prinsepia utilis & 60 & 1.167 & 0.7 & 16.11 & 82.785 & 0.0194 \\
\hline & & 170 & & 2.90 & 68.97 & 300 & \\
\hline & Herb & & & & & & \\
\hline & Agrostis nervosa & 100 & 5.7 & 5.7 & 1.82 & 58.985 & 0.057 \\
\hline & Arundinela nepalensis & 90 & 7.333 & 6.6 & 2.10 & 63.693 & 0.0815 \\
\hline & Chrysopogon aciciculatus & 60 & 3.333 & 2 & 0.64 & 25.145 & 0.0556 \\
\hline & Chrysopogon fulvus & 50 & 4.6 & 2.3 & 1.65 & 35.081 & 0.092 \\
\hline & Hedychium spicatum & 70 & 3.571 & 2.5 & 0.80 & 30.538 & 0.051 \\
\hline & Polygonum chinensis & 70 & 4.857 & 3.4 & 1.08 & 37.032 & 0.0694 \\
\hline & Polygonum lanigerum & 60 & 3.333 & 2 & 0.64 & 25.145 & 0.0556 \\
\hline & Achyranthis bidentata & 60 & 2 & 1.2 & 0.86 & 24.359 & 0.0333 \\
\hline & & 560 & & 25.70 & 9.58 & 299.98 & \\
\hline
\end{tabular}

F, Frequency; A, Abundance; D, Density; TBC, Total Basal Cover; IVI, Importance Value Index; A/F, Abundance/Frequency ratio.

reported for oak and chir pine forests of Kumaun (Tewari and Singh, 1985) and Garhwal (Bhandari et al., 1997) Himalaya, respectively. Little difference in the beta-diversity indicates that the growth forms among different stands respond in similar fashion (Adhikari et al., 1991). These values of beta diversity show that the species composition varies across the slopes and aspects.
Values on concentration dominance $(\mathrm{Cd})$ are similar to that reported by Whittaker (1965) and Risser and Rice (1971) ranging from 0.19 to 0.99 for certain temperate vegetation. The values of concentration of dominance (Cd) of the present study ranged from 0.2438 to 0.3993 , 0.2008 to 0.4789 and 0.1318 to 0.1736 , respectively for trees, shrubs and herbs layer for montane forests of 
Table 3. Contd.

\begin{tabular}{|c|c|c|c|c|c|c|c|}
\hline Site & Botanical name & $\mathbf{F}$ & A & D & TBC & IVI & $\mathbf{A} / \mathbf{F}$ \\
\hline & Tree & & & & & & \\
\hline & Quercus floribunda & 40 & 3.25 & 1.3 & 2956.15 & 40.97 & 0.0813 \\
\hline & Q. leucotrichophora & 80 & 3.25 & 2.6 & 5704.27 & 80.77 & 0.0406 \\
\hline & Neolitsea pallens & 100 & 3.4 & 3.4 & 5770.25 & 94.915 & 0.034 \\
\hline & Acer ceasium & 50 & 0.8 & 0.4 & 624.20 & 20.921 & 0.016 \\
\hline & Aesculus indica & 60 & 1.833 & 1.1 & 1390.41 & 35.306 & 0.0306 \\
\hline & Symplocos ramosissima & 50 & 1.2 & 0.6 & 1348.28 & 27.118 & 0.024 \\
\hline & & 380 & & 9.40 & 17793.57 & 300 & \\
\hline & Sapling & & & & & & \\
\hline & Quercus floribunda & 60 & 2 & 1.2 & 46.24 & 79.083 & 0.0333 \\
\hline & Acer ceasium & 90 & 1.778 & 1.6 & 99.87 & 127.38 & 0.0198 \\
\hline & Aesculus indica & 70 & 1.571 & 1.1 & 73.65 & 93.538 & 0.0224 \\
\hline & & 220 & & 3.90 & 219.77 & 300 & \\
\hline \multirow{19}{*}{$\begin{array}{l}\text { Site 4: Bamyala } \\
(2000-2500)\end{array}$} & Seedling & & & & & & \\
\hline & Quercus floribunda & 80 & 3.25 & 2.6 & 1.19 & 128.15 & 0.0406 \\
\hline & Q. leucotrichophora & 90 & 2.111 & 1.9 & 1.36 & 125.49 & 0.0235 \\
\hline & Acer ceasium & 30 & 2.667 & 0.8 & 0.50 & 46.467 & 0.0889 \\
\hline & & 200 & & 5.30 & 3.05 & 300 & \\
\hline & Shrub & & & & & & \\
\hline & Daphne papyracea & 100 & 3.9 & 3.9 & 124.20 & 171.17 & 0.039 \\
\hline & Pyracantha crenulata & 40 & 1.75 & 0.7 & 37.68 & 47.455 & 0.0438 \\
\hline & Rosa brunonii & 80 & 1.125 & 0.9 & 18.34 & 55.861 & 0.0141 \\
\hline & Rosa macrophylla & 40 & 1 & 0.4 & 6.24 & 25.512 & 0.025 \\
\hline & & 260 & & 5.90 & 186.46 & 300 & \\
\hline & Herb & & & & & & \\
\hline & Arundo donax & 90 & 4 & 3.6 & 1.79 & 43.621 & 0.0444 \\
\hline & Agrostis pilsula & 90 & 4.111 & 3.7 & 1.95 & 45.16 & 0.0457 \\
\hline & Chrysopogon aciciculatus & 100 & 4.7 & 4.7 & 3.37 & 61.443 & 0.047 \\
\hline & Eriophorum comosum & 100 & 3 & 3 & 2.15 & 45.678 & 0.03 \\
\hline & Roscoea alpina & 90 & 6.222 & 5.6 & 2.79 & 58.926 & 0.0691 \\
\hline & Polygonum chinensis & 90 & 5.111 & 4.6 & 1.46 & 45.172 & 0.0568 \\
\hline & & 560 & & 25.2 & 13.51 & 300 & \\
\hline
\end{tabular}

F, Frequency; A, Abundance; D, Density; TBC, Total Basal Cover; IVI, Importance Value Index; A/F, Abundance/Frequency ratio.

Saikot Reserve Forest. Mean (Cd) values of 0.31 to 0.42 (Mishra et al., 2000) and 0.07 to 0.25 (Shivnath et al., 1993) were reported earlier from other parts of Indian Himalaya. The higher value of $\mathrm{Cd}$ in the forest growing on upper altitude was due to lower species richness (Bhatt and Purohit, 2009). According to Baduni and Sharma (1997), the Cd or Simpson's index was strongly affected by the IVI of the first three relatively important species in a community. Species diversity and dominance (Simpson index) are inversely related to each other (Zobel et al., 1976).

\section{Conclusion}

Generally, $P$. roxburghii forms the climax vegetation at lower altitude and $Q$. leucotrichophora forms at middle altitudes (1500-2000). However, due to the anthropogenic pressure, water table seems to reduce which is providing the suitable condition for $P$. roxburghii invasion at higher elevation and north aspect and this invasion leads to mixed community of oak-pine patches at north aspect and in higher elevation, indicating developmental stage of secondary succession. As a result, it may be 
Table 4. Distribution pattern of different forest sites of Saikot reserve forest.

\begin{tabular}{|c|c|c|c|c|}
\hline \multirow{2}{*}{ Site } & \multirow{2}{*}{ Stratum } & \multicolumn{3}{|c|}{ Distribution pattern (\%) } \\
\hline & & Regular & Random & Contagious \\
\hline \multirow{3}{*}{ Site 1 (Saikot) } & Tree & 14.29 & 85.71 & \\
\hline & Shrubs & 33.33 & 66.67 & \\
\hline & Herbs & 45.46 & 9.09 & 45.45 \\
\hline \multirow{3}{*}{ Site 2 (Tangsa) } & Tree & 42.86 & 57.14 & \\
\hline & Shrubs & 25.00 & 50.00 & 25.00 \\
\hline & Herbs & 14.29 & 14.29 & 71.43 \\
\hline \multirow{3}{*}{ Site 3(Devkhal) } & Tree & 22.22 & 66.67 & 11.11 \\
\hline & Shrubs & 33.33 & 66.67 & \\
\hline & Herbs & & 12.5 & 87.5 \\
\hline \multirow{3}{*}{ Site 4 (Bamyala) } & Tree & 33.33 & 50.00 & 16.67 \\
\hline & Shrubs & 50.00 & 50.00 & \\
\hline & Herbs & 16.67 & 50.00 & 33.33 \\
\hline
\end{tabular}

Table 5. Species diversity $\left(\mathrm{H}^{-}\right)$, concentration of dominance (CD) and equitability of different forest sites of Saikot Reserve Forest.

\begin{tabular}{lcccc}
\hline Site & $\left.\mathbf{( H}^{-}\right)$ & $\mathbf{C D}$ & Equitability & $\boldsymbol{\beta}$ diversity \\
\hline Saikot (I) Tree & 1.3266 & 0.3993 & 5.294129 & 2.33333 \\
Sapling & 2.2177 & 0.6676 & 3.484131 & 2.5 \\
Seedling & 2.0263 & 0.6099 & 3.321928 & 3 \\
Shrubs & 0.66737 & 0.20089 & 9.548227 & 1.81818 \\
Herbs & 0.4377 & 0.1318 & 8.763037 & 2.29167 \\
& & & & \\
Tangsa (II) Tree & 0.9490 & 0.2857 & 5.214453 & 1.75 \\
Sapling & 1.2239 & 0.3684 & 8.51831 & 2.30769 \\
Seedling & 1.6815 & 0.5062 & 20.6377 & 2 \\
Shrubs & 1.0632 & 0.3200 & 7.475054 & 1.73913 \\
Herbs & 0.5421 & 0.1632 & 12.86604 & 1.94444 \\
& & & & \\
Devkhal (III) Tree & 0.8098 & 0.2438 & 6.60925 & 2 \\
Sapling & 1.2766 & 0.3843 & 6.828538 & 1.875 \\
Seedling & 1.5829 & 0.4765 & 4.189925 & 1.5 \\
Shrubs & 1.2759 & 0.3841 & 9.06363 & 1.76471 \\
Herbs & 0.5462 & 0.1644 & 10.80551 & 1.42857 \\
& & & & \\
Bamyala (IV) Tree & 0.8173 & 0.2460 & 6.455646 & 1.57895 \\
Sapling & 1.3021 & 0.3920 & 18.43575 & 1.36364 \\
Seedling & 1.1379 & 0.3425 & 5.86071 & 1.5 \\
Shrubs & 1.5909 & 0.4789 & 4.044471 & 1.53846 \\
Herbs & 0.57679 & 0.17363 & 22.13477 & 1.07143 \\
\hline
\end{tabular}

concluded that due to anthropogenic disturbances these forests are in unstable and in degrading stage therefore, immediate steps should be taken to save these ecologi- cally and economically important forests and species. As per the Champion and Seth (1968) classification, the Saikot Forest broadly falls under the Himalayan moist 
Table 6. Community coefficient of different forest sites of Saikot Reserve Forest.

\begin{tabular}{lcccc}
\hline Site 1 & Site 1 & Site 2 & Site 3 & Site 4 \\
\hline Tree & 100 & 33.52 & Dissimilar & Dissimilar \\
Sapling & 100 & 20.52 & Dissimilar & Dissimilar \\
Seedling & 100 & 41.02 & Dissimilar & Dissimilar \\
Shrub & 100 & 60.55 & Dissimilar & Dissimilar \\
Herb & 100 & 13.88 & Dissimilar & Dissimilar \\
& & & \\
Site 2 & & & & \\
Tree & 100 & 25 & 26.53 \\
Sapling & & 100 & 29.26 & Dissimilar \\
Seedling & 100 & 33.89 & 28.16 \\
Shrub & 100 & Dissimilar & Dissimilar \\
Herb & 100 & 17.30 & Dissimilar \\
& & & & \\
Site 3 & & 100 & 10.57 \\
Tree & & 100 & Dissimilar \\
Sapling & & 100 & 51.06 \\
Seedling & & 100 & 50 \\
Shrub & & 100 & 21.21 \\
Herb & & & \\
Site 4 & & & 100 \\
Tree & & & 100 \\
Sapling & & & 100 \\
Seedling & & & 100 \\
Shrub & & & \\
Herb & & & & \\
\hline
\end{tabular}

temperate forests category.

\section{Conflict of Interests}

The author(s) have not declared any conflict of interests.

\section{ACKNOWLEDGEMENTS}

The authors are thankful to the editorial board and reviewers for improving the manuscript.

\section{REFERENCES}

Adhikari BS, Rikhari HC, Rawat YS, Singh SP (1991). High altitude forests composition, diversity and profile structures in a part of Kumaun Himalaya. Trop. Ecol. 32:86-97.

Agrawal B (1985). Effect of surface burning on vegetation composition, Net primary productivity, and mineral cycling in the submontane grassland at Srinagar. D Phil Thesis, HNB University of Garhwal, Srinagar, India.

Ahmed M, Khan N, Wahab M, Hamza S, Siddiqui MF, Nazim K, Khan MU (2010). Description and structure of Olea ferruginea (Royle) forest of Dir Lower District of Pakistan. Pak. J. Bot. 41(6):2683-2683.
Ahmed M, Hussain T, Sheikh AH, Hussain SS, Siddiqui MF (2006). Phytosociology and structure of Himalayan forests from different climatic zones of Pakistan. Pak. J. Bot. 38(2):361-383.

Baduni NP, Sharma CM (1997). Effect of aspect on the structure of some natural stands of Cupressus torulosa in Himalaya moist temperate forests. Pro. Ind. Natl Sci. Acad. 1362:345-352.

Bankoti TNS, Melkania U, Saxena AK (1986). Vegetation analysis along an altitudinal gradient in Kumaun Himalaya. Indian J. Ecol. 13:211221.

Becking R (1954). Site indicators and forest types of the Douglas fir region of western Washington and Oregon. Ph.D. thesis, Univ. Washington, Seattle.

Beg AR, Khan MH (1984). Some more plant communities and the future of dry oak forest zone in Swat valley. Pak. J. Forest. 34: 25-35.

Bhandari BS, Mehta JP, Trivedi SC (1995). Vegetation structure under different management regimes in a grazinglind at Srinagar (Garhwal) J. Hill Res. 8:39-46.

Bhandari BS, Mehta JP, Nautiyal BP, Tiwari SC (2003). Blue Pine (Pinus wallichiana) forest stand of Garhwal Himalaya: composition, population structure and diversity. J. Trop. For. Sci. 15 (1):26-36.

Bhandari BS, Tiwari SC (1997). Dominance and diversity along an altitudinal gradient in a montane forest of Garhwal Himalaya. Proc. Indian Natl. Sci. Acad. B 64:437-446.

Bhandari BS, Mehta JP, Tiwari SC (1998). Dominance and diversity relations of woody vegetation structure along an altitudinal gradient in a montane forest of Garhwal Himalaya. J. Trop. Fore. Sci. 12 (1):4961.

Bhandari BS, Mehta JP, Nautiyal BP, Tiwari SC (1997). Structur of Chir pine (Pinus roxburghii) community along an altitudinal gradient in Garhwal Himalaya. 
Bhatt VP, Purohit VK (2009). Floristic structure and phytodiversity along an elevational gradient in Peepalkoti-Joshimath area of Garhwal Himalaya, India. Nat. Sci. 7(9)63-74.

Bisht NS, Kusumlata (1993). Niche width and dominance diversity relation of woody diversity in a moist temperate forest of Garhwal Himalaya. J. Hill Res. 6:107-113.

Champion HG, Seth SK (1968a). A Revised survey of Forest Types of India. Govt of India Publication, Delhi.

Champion HG, Seth SK (1968b). A revised survey of the forest types of India. Manager of Publications, Delhi.

Cheema MSZA, Qadir SA (1973). Autecology of Acacia Senegal (L.) Willd. Vegetatio, 27(1):131-162.

Curtis JT, Cottom G (1956). Plant ecology work laboratory field reference manual. Burges Publishing Co. Minnosota.

Gaur RD (1999).Flora of District Garhwal NW Himalaya (With ethnobotanical notes)

Gaur RD, Bartwal BS (1993). Different types of forest communities of Pauri Distt. Garhwal Himalaya, In: G S Rajwar (Ed) Garhwal Himalaya: Ecol. Environ.1:131-147, New Delhi.

Greig-Smith P (1957). Quantitative Plant Ecology. 2nd Edition. Bulterworth, London.

Joshi NK, Tiwari SC (1990). Phytosociological analysis of woody vegetation along an altitudinal gradient in Garhwal Himalaya. Ind J. For. 13:322-328.

Kershaw KA (1973). Quantitative and Dynamic Plant Ecology. (London: Edward Arnold Ltd.) p. 308

Khan N, Ahmed M, Wahab M, Ajaib M (2010a). Studies along an altitudinal gradient in Monotheca buxifolia forest District Dir Lower Pakistan. Pak. J. Bot.

Kharkwal G, Mehrotra P, Rawat YS, Pangtey YPS (2005). Phytodiversity and growth form in relation to altitudinal gradient in the Central Himalayan (Kumaun) region of India, Current Science, 89(5): 873-878.

Kuczynski S (1927). International Acad. Polln. Sci. Letter Bull., Classe. Sci. et Nat. Ser. Sci.

Maikhuri RK, Nautiyal S, Rao KS, Chandrasekhar K, Gavali R, Saxena KG (2000). Analysis and resolution of protected area - people conflicts in Nanda Devi Biosphere Reserve, India, Environmental Conservation 26 (4): Management. Edited by P.S. Ramakrishnan, K..G. Saxena and U.M. Chandrashekara, Oxford and IBH Publishing Co., Ltd., New Delhi. pp. 289-299.

Mehta JP, Tiwari SC (1992). Structure of primary producers in a montane grazing lands of Garhwal Himalaya under burnt, burnt grazed and protection against herbage removal regimes. In: G S Rajwar (ed) Garhwal Himalaya: Ecology and Environment.1: 173193, New Delhi.

Mehta JP, Tiwari SC, Bhandari BS (1997). Phytosociology of woody vegetation under different management regimes in Garhwal Himalaya. J. Trop. For. Sci. 10 (1):24-34.

Mehta JP; Tiwari SC, Bhandari BS (1997). Phytosociology of woody vegetation under different management regimes in Garhwal Himalaya. J. Trop. For. Sci. 10 (1) 24-34.

Mishra A, Sharma CM, Sharma SD, Baduni NP (2000). Effect of aspect on the structure of vegetation community of moist bhabar and tarai Shorea robusta forest in Central Himalaya. Indian Forester. 126(6):634-642.

Nautiyal BP, Pandey, Nirmala, Bhatt AB (1997). Analysis of vegetation pattern in an alpine zone in north-west Himalaya: A case study of Garhwal Himalaya with reference to diversity and distribution pattern. Ind. J. Ecol. Envi. Eci. 23:49-65.

Osmoston $A E$ (1922). Notes on the forest communities of Garhwal Himalaya. J. Ecol. 10: 129-169.

Puri GS (1960). Indian Forest Ecology. Oxford and IBH Publishing Co. New Delhi. p. 318.

Ralhan PK, Saxena AK, Singh JS (1982). Analysis of forest vegetation at and around Nainital in Kumaun Himalaya. Proc. Ind. Nat. Sci. Acad. B 48:121-137.
Rawat KS, Tiwari SC (1990). Effect of wild-fire on vegetation composition in oak forest of Garhwal Himalaya. In G S Rajwar (ed) Progress of Ecoloy, New Delhi.

Risser PG, Rice EL (1971). Diversity in tree species in Oklahoma Upland forests. Ecology, 52:783-800.

Saxena AK, Singh JS (1982). A phytosociological analysis of woody sepcies in forest communities of a part of Kumaun Himalaya. Vegetation. 50:3-32.

Saxena AK, Singh JS (1984). Tree population structure of certain Himalayan forest associations and implications concerning their future composition, Vegetatio. 58:61-69.

Saxena AK, Pandey U, Singh JS (1978). On the ecology of oak forest in Nainital Hills, Kumoun Himalaya. In: J.S. Singh and Brij Gopal (Eds.) Glimpses of Ecology: Prof. R. Misra Commemoration Volume. Jaipur Intl. Sci. Pub. 167-180.

Semwal RL, Mehta JP (1996). Ecology of forest fires in Chir - pine (Pinus roxburghii Sarg.) forests of Garhwal Himalaya. Curr. Sci. 70:426-427.

Shannon CE, Wiener WE (1963). The Mathematical Theory of Communication. University of Illinois Press, Urbana, USA. 117pp.

Shivnath S, Gupta K, Rajwar GS (1993). Analysis of forest vegetation in a part of Garhwal Himalaya. Recent Res. Ecol. Environ Pollu. 6:4758.

Simpson EH (1949). Measurement of diversity. Nature 163-188.

Singh JS, Singh SP (1987). Forest vegetation of Himalaya. Bot. Rev. 52: 80-192.

Singh JS, Yadava PS (1974). Seasonal variation in composition, plant biomass and net primary productivity of a Tropical grassland at Kurukshetra, India. Ecol. Monograph. 44:351 -375.

Singh JS, Chaturvedi OP, Rawat YS (1984). Replacement of oak forest with pine in the Himalaya affects the nitrogen cycle. Nature 311:5456.

Singh JS, Rawat YS, Garkoti SC (1997). Failure of brown oak (Q. semicarpifolia) to regenerate in Central Himalaya: a case of environmental semisurprise. Curr. Sci. 73(4):371-374.

Sinha B, Maikhuri RK (1998). Conservation through 'Socio-cultural religious Practice' in Garhwal Himalaya: A Case Study of Hariyali Sacred Site. In: Conserving the Sacred for Biodiversity

Thadani R, Ashton PMS (1995). Regeneration of banj-oak ( $Q$ leucotrichophora A. Camus) in the Central Himalaya. For. Ecol. Manag. 78:217-224.

Tiwari JC, Singh SP (1985). Analysis of woody vegetation in a mixed oak forest of Kumaun Himalaya. Proc. Indian Natl. Sci. Acad. 51(B):232-347.

Tiwari SC (1979). Studies on phytosociological plant biomass and net primary productivity of four grassland communities of Pauri Hills, Garhwal Himalaya. D Phil Thesis, Garhwal University Srinagar Garhwal, Srinagar, India.

Tiwari SC, Gupta SK (1982). Grassland ecology of Garhwal Himalaya with reference to micro- climate and phytosociology. In: G S Paliwal (ed). The vegetational wealth of the Himalaya. Pooja Publishers. Delhi.

Whittaker RH (1975). Communities and Ecosystems. 2nd ed. Mac Millan Publishing Co., New York. p. 385.

Whittaker RH (1965). Dominance and Diversity in Land Plant Communities, Science 147:250-260.

Whittaker RH (1972). Communities and Ecosystems. 2nd ed. Macmillan Pub. Co. New York, U.S.A., 385.

Wikum DA, Wali MK (1974). Analysis of North Dakota Gallery forest vegetation in relation to topographic and soil gradients. Ecol. Monogr. 44:441-464.

Yadav AS, Gupta SK (2006). Effect of microenvironment and human disturbance on the diversity of woody species in the Sariska Tiger Project in India. For. Ecol. Manag. 225:178-189. 